\title{
Phenolic Antioxidants from the Heartwood of Acacia confusa
}

\author{
Jyh-Horng Wu,${ }^{\dagger}$ Yu-TAng Tung, ${ }^{\dagger}$ Sheng-YAng Wang,${ }^{\ddagger}$ LIE-Fen Shyur,${ }^{\S}$ \\ Yueh-Hsiung Kuo," and Shang-Tzen Chang*, ${ }^{*}$
}

\begin{abstract}
School of Forestry and Resource Conservation, National Taiwan University, Taipei 106, Taiwan, Department of Forestry, National Chung-Hsing University, Taichung 402, Taiwan, Institute of BioAgricultural Sciences, Academia Sinica, Taipei 115, Taiwan, and Department of Chemistry, National Taiwan University, Taipei 106, Taiwan
\end{abstract}

\begin{abstract}
In the present study, the ethanolic extracts from the heartwood of Acacia confusa, a species indigenous to Taiwan, exhibit strong antioxidant effects. Among all the fractions from ethanolic extracts of heartwood, the EtOAc soluble fraction exhibits the best antioxidant activity. The $80 \%$ 1,1-diphenyl2-picrylhydrazyl radical inhibitory activity by the EtOAc extract was observed at a concentration of 5 $\mu \mathrm{g} / \mathrm{mL}$, and at the same dosage there was a similar free radical scavenging activity for (-)-ascorbic acid and (+)-catechin, both of which are well-known antioxidants. In addition, the EtOAc extract also protects $\Phi \times 174$ supercoiled DNA against strand scission induced by hydroxyl radical. Furthermore, following by column chromatography and reverse-phase high-performance liquid chromatorgrapy, 10 pure phenolic compounds, including three major antioxidants $\left(3,7,8,3^{\prime}, 4^{\prime}\right.$-pentahydroxyflavone,

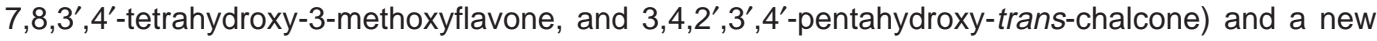
flavonoid (3,7,8,3'-tetrahydroxy-4'-methoxyflavone), were isolated from the ethanolic extracts of $A$. confusa heartwood.
\end{abstract}

KEYWORDS: Acacia confusa; antioxidant; flavonoids; free radical; phenolic compounds

\section{INTRODUCTION}

Antioxidants are compounds that can delay or prevent the oxidation of lipids or other molecules by inhibiting the initiation or propagation of oxidative chain reactions (1). Plants are potential sources of natural antioxidants, and certain species are particularly significant because they may be used for the production of raw materials or preparations containing phytochemicals with significant antioxidant capacities and health benefits (2). The antioxidative effect is mainly due to phenolic compounds, such as flavonoids, phenolic acids, tannins, and phenolic diterpenes (3-5). In addition, numerous studies have revealed that some phenolic molecules have anticancer, anticarcinogenic, and antimutagenic activities. Furthermore, these bioactivities of phenolics might be related to their antioxidant properties and/or the modulation of several protein functions $(6-8)$.

Flavonoids are low molecular weight polyphenolic substances based on the flavan nucleus and are plentiful in the heartwood of several Acacia species, belonging to the family Leguminosae $(9,10)$. Acacia confusa Merr., a species indigenous to Taiwan, is widely distributed over the hills and lowlands of Taiwan and

* To whom correspondence should be addressed. Tel: 886-2-33664626 Fax: 886-2-23654520. E-mail: peter@ntu.edu.tw.

† School of Forestry and Resource Conservation, National Taiwan University.

$\doteqdot$ National Chung-Hsing University.

$\S$ Academia Sinica.

" Department of Chemistry, National Taiwan University. is traditionally used as a medicinal plant. An aqueous extract of A. confusa leaves was used in Taiwan for wound healing and antiblood stasis (11). Moreover, in a previous study, we found that the ethanolic extracts of the heartwood not only contain a large amount of phenolics but also show an excellent antioxidant activity (12). Therefore, this plant might be a good candidate for further development of its nutraceutical or antioxidant potential. However, to date the potential health benefits of the heartwood extracts of $A$. confusa have not been studied in detail. In this study, column chromatography (CC) and high-performance liquid chromatography (HPLC) were employed to separate and purify the A. confusa heartwood extracts, and their antioxidant activities were further evaluated by various assays, including in vitro free radical scavenging assay and hydroxyl radical-induced DNA strand scission assay. In addition, the chemical structure of antioxidative compounds was identified by mass spectrometry and nuclear magnetic resonance (NMR) spectrometry analyses.

\section{MATERIALS AND METHODS}

Chemicals. 1,1-Diphenyl-2-picrylhydrazyl (DPPH), hypoxanthine, xanthine oxidase, nitroblue tetrazolium chloride (NBT), 2-thiobarbituric acid (TBA), ФX174 RF1 supercoiled DNA, Folin-Ciocalteu reagent, $(-)$-ascorbic acid, and (+)-catechin were all purchased from Sigma Chemical Co. (St. Louis, MO). The other chemicals and solvents used in this experiment were of the highest quality available.

Preparation of Plant Extracts. Heartwood of A. confusa was sampled from the experimental forest of National Taiwan University 
<smiles>O=C(O)c1ccc(O)c(O)c1</smiles>

1<smiles>COC(=O)c1ccc(O)c(O)c1</smiles>

5<smiles>CCOC(=O)c1ccc(O)c(O)c1</smiles>

8<smiles>O=C1c2ccc(O)c(O)c2O[C@H](c2ccc(O)c(O)c2)C1O</smiles>

2<smiles>COc1ccc(C(=O)O)cc1O</smiles>

3

4<smiles>COc1c(-c2ccc(O)c(O)c2)oc2c(O)c(O)ccc2c1=O</smiles>
7
6<smiles>O=C(/C=C/c1ccc(O)c(O)c1)c1ccc(O)c(O)c1O</smiles><smiles>COc1ccc(-c2oc3c(O)c(O)ccc3c(=O)c2O)cc1O</smiles>

10

Figure 1. Phenolic compounds isolated from EA3 subfraction of the heartwood of $A$. confusa. 1, 3,4-Dihydroxybenzoic acid; 2, 2,3-trans-7,8,3',4'tetrahydroxydihydroflavonol; 3, 3-hydroxy-4-methoxybenzoic acid; 4, 7,8,3',4'-tetrahydroxyflavanone; 5, 3,4-dihydroxybenzoic acid methyl ester; 6, 3,7,8,3',4'-

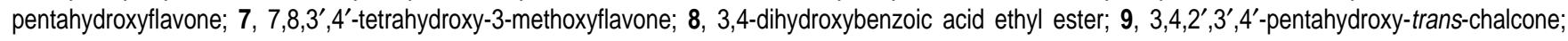
10, 3,7,8,3'-tetrahydroxy-4'-methoxyflavone.

in Nan-Tou County. The species was identified by Sheng-You Lu of the Taiwan Forestry Research Institute, and a voucher specimen (AC001) was deposited at School of Forestry and Resource Conservation, National Taiwan University. The dried samples $(1.65 \mathrm{Kg})$ were cut into small pieces and soaked in $70 \%$ ethanol at room temperature for 7 days. The extract was decanted, filtered under vacuum, concentrated in a rotary evaporator, and then lyophilized. The resulting crude extract $(135 \mathrm{~g})$ was extracted successively with $n$-hexane $\left(n-\mathrm{C}_{6} \mathrm{H}_{14}\right)$, ethyl acetate (EtOAc), butanol $(\mathrm{BuOH})$, and water to yield the $n-\mathrm{C}_{6} \mathrm{H}_{14}$ (1 g), EtOAc (84 g), $\mathrm{BuOH}(20 \mathrm{~g})$, and $\mathrm{H}_{2} \mathrm{O}(13 \mathrm{~g})$ soluble fractions and a water-insoluble fraction $(17 \mathrm{~g})$. The EtOAc soluble fraction was divided into eight subfractions (EA1-EA8) by chromatography with a Lichroprep RP-18 gel (Merck, Darmstadt, Germany) column eluted with $\mathrm{MeOH} / \mathrm{H}_{2} \mathrm{O}$ (gradient elution was performed by changing from 10/90 to 100/0). Ten compounds, as shown in Figure 1, were isolated and purified from the EA3 subfraction by semipreparative HPLC on a model PU-980 instrument (Jasco, Japan) with a $250 \times 21.2 \mathrm{~mm}$ inside diameter, $7 \mu \mathrm{m}$ Zorbax RP-18 column (Agilent Technologies, Palo Alto, CA). Mobile phase: solvent A, $100 \% \mathrm{MeOH}$; solvent $\mathrm{B}, \mathrm{H}_{2} \mathrm{O}$. Elution conditions were the following: $0-5 \mathrm{~min}$ of $10-20 \% \mathrm{~A}$ to $\mathrm{B}$ (linear gradient); 5-35 min of 20-65\% A to B (linear gradient); 35-45 min of $65-100 \%$ A to B (linear gradient); flow rate, $10 \mathrm{~mL} / \mathrm{min}$; detector, Jasco MD-910 photodiode array at $254 \mathrm{~nm}$ wavelength. UV spectra of test compounds were recorded with a Jasco V-550 spectrometer, and IR spectra were obtained from a Bio-Rad FTS-40 spectrophotometer. Electron-impact mass spectrometry (EIMS) and high-resolution electronimpact mass spectrometry (HREIMS) data were collected with a Finnigan MAT-958 mass spectrometer, and NMR spectra were record with Bruker Avance 500 and $300 \mathrm{MHz}$ FT-NMR spectrometers.

$\mathbf{3 , 7 , 8 , 3}$ '-Tetrahydroxy-4'-methoxyflavone (10). Light-yellow amorphous solid. UV (MeOH), $\lambda_{\max }, \mathrm{nm}(\log \epsilon): 258.5$ (4.48), 368.5 (4.39). IR (KBr), $v_{\max }, \mathrm{cm}^{-1}: 3335,1617,1555,1517,1432,1320$. HREIMS $m / z: 316.0584,[\mathrm{M}]^{+}$calcd 316.0583 for $\mathrm{C}_{16} \mathrm{H}_{12} \mathrm{O}_{7} .{ }^{1} \mathrm{H}$ NMR (DMSO$\left.d_{6}, 500 \mathrm{MHz}\right) \delta 7.76\left(1 \mathrm{H}, \mathrm{s}, \mathrm{H}-2^{\prime}\right), 7.74\left(1 \mathrm{H}, \mathrm{d}, J=8.5 \mathrm{~Hz}, \mathrm{H}-6^{\prime}\right)$, $7.42(1 \mathrm{H}, \mathrm{d}, J=8.7 \mathrm{~Hz}, \mathrm{H}-5), 7.08\left(1 \mathrm{H}, \mathrm{d}, J=8.5 \mathrm{~Hz}, \mathrm{H}-5^{\prime}\right), 6.92$ $(1 \mathrm{H}, \mathrm{d}, J=8.7 \mathrm{~Hz}, \mathrm{H}-6), 3.83\left(3 \mathrm{H}, \mathrm{s}, 4^{\prime}-\mathrm{OCH}_{3}\right) .{ }^{13} \mathrm{C}$ NMR (DMSO$\left.d_{6}, 125 \mathrm{MHz}\right) \delta 172.4(\mathrm{C}-4), 149.7$ (C-7), 149.0 (C-4'), 146.1 (C-3'), 145.9 (C-9), 144.5 (C-2), 137.2 (C-3), 132.7 (C-8), 124.3 (C-1'), 119.8 (C-6'), 115.1 (C-5 and C-10), 114.7 (C-2'), 113.9 (C-6), 111.7 (C-5'), $55.6\left(4^{\prime}-\mathrm{OCH}_{3}\right)$.
Rapid Screening of Antioxidants by Thin-Layer Chromatography (TLC) Analysis and DPPH Staining. Drops $(1 \mu \mathrm{L})$ of each EA subfraction (EA1-EA8) separated from the ethyl acetate soluble fraction were located individually on the baseline of the RP- $18 \mathrm{~F}_{254} \mathrm{~S}$ TLC layer (Merck, Darmstadt, Germany), which was then developed with $50 \%$ methanol/water (v/v). The layer was dried and stained with $0.2 \% \mathrm{DPPH}$ $(w / v)$ solution in ethanol.

Free Radical Scavenging Activity. The scavenging activity of DPPH free radical by A. confusa heartwood extract was determined according to the method reported by Gyamfi et al. (13). Heartwood extract of $A$. confusa in methanol $(50 \mu \mathrm{L})$, yielding a series of extract concentrations of $1,5,10$, and $50 \mu \mathrm{g} / \mathrm{mL}$, respectively, in each reaction, was mixed with $1000 \mu \mathrm{L}$ of $0.1 \mathrm{mM}$ DPPH-ethanol solution and 450 $\mu \mathrm{L}$ of $50 \mathrm{mM}$ Tris $-\mathrm{HCl}$ buffer (pH 7.4). Methanol $(50 \mu \mathrm{L})$ alone was used as a control of this experiment. After $30 \mathrm{~min}$ of incubation at room temperature, the reduction of the DPPH free radical was measured by reading the absorbance at $517 \mathrm{~nm}$. (-)-Ascorbic acid and (+)catechin were used as positive controls. The inhibition ratio (percent) was calculated from the following equation: $\%$ inhibition $=[($ absorbance of control - absorbance of test sample)/absorbance of control] $\times 100$.

DNA Strand Scission by Hydroxyl Radicals. The assay was done according to the method of Keum et al. (14). The reaction mixture (30 $\mu \mathrm{L}$ ) contained $10 \mathrm{mM}$ Tris $-\mathrm{HCl}-1 \mathrm{mM}$ EDTA buffer $(\mathrm{pH} 8.0$ ), $\Phi X 174 \mathrm{RF} 1 \mathrm{DNA}(0.3 \mu \mathrm{g})$, and $\mathrm{H}_{2} \mathrm{O}_{2}(0.04 \mathrm{M})$. Various amounts of the test extract samples dissolved in $10 \mu \mathrm{L}$ of ethanol (final concentrations of the plant extract in each assay were $1,10,100,500$, and 1000 $\mu \mathrm{g} / \mathrm{mL}$, respectively) were added prior to $\mathrm{H}_{2} \mathrm{O}_{2}$ addition. Hydroxyl radicals were generated by irradiation of the reaction mixtures at a distance of $5 \mathrm{~cm}$ with a Spectroline 12-W UV lamp (Spectronics Co., Westbury, NY). After incubation at room temperature for $20 \mathrm{~min}$, the reaction was terminated by the addition of a loading buffer $(0.25 \%$ bromophenol blue tracking dye and $40 \%$ sucrose), and the mixtures were then analyzed by $0.8 \%$ submarine agarose gel electrophoresis (70 $\mathrm{eV}, 1 \mathrm{~h}$ ). The gels were stained with ethidium bromide, destained in water, and photographed on a transilluminator.

Determination of Total Phenolics. Total phenolic content was determined according to the Folin-Ciocalteu method (15), using gallic acid as the standard. The heartwood extract ( $5 \mathrm{mg}$ ) of $A$. confusa was dissolved in $5 \mathrm{~mL}$ of methanol/water $(50: 50, \mathrm{v} / \mathrm{v})$. The extract solution 


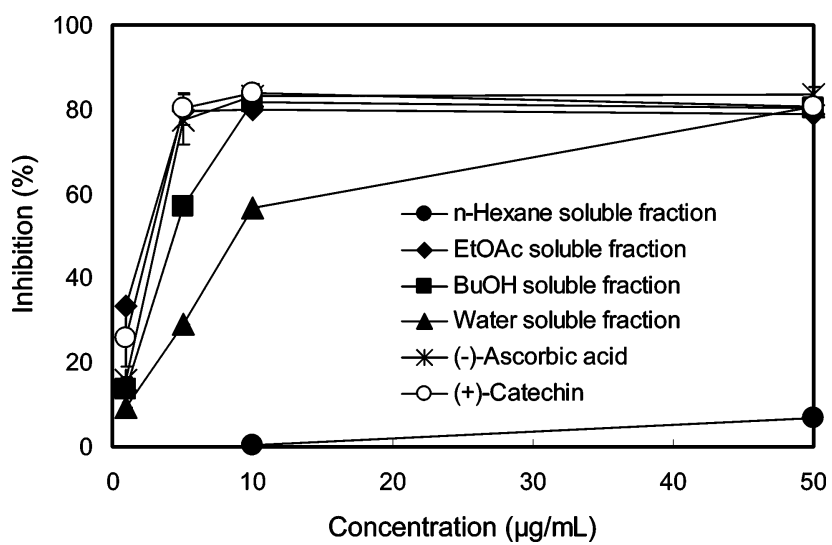

Figure 2. Free radical scavenging activity of fractions from the ethanolic extracts of the heartwood of $A$. confusa measured by the DPPH assay. Results are mean $\pm \operatorname{SD}(n=3)$.

$(500 \mu \mathrm{L})$ was mixed with $500 \mu \mathrm{L}$ of $50 \%$ Folin-Ciocalteu reagent. The mixture was kept for a $2-5 \mathrm{~min}$ period, which was followed by the addition of $1.0 \mathrm{~mL}$ of $20 \% \mathrm{Na}_{2} \mathrm{CO}_{3}$. After $10 \mathrm{~min}$ of incubation at room temperature, the mixture was centrifuged for $8 \mathrm{~min}(150 \mathrm{~g})$, and the absorbance of the supernatant was measured at $730 \mathrm{~nm}$. The total phenolic content was expressed as gallic acid equivalents (GAE) in milligrams per gram sample.

Statistical Analyses. All results were expressed as mean \pm SD ( $n$ $=3$ ). The significance of difference was calculated by SAS Scheffe's test, and values $<0.05$ were considered to be significant.

\section{RESULTS}

Free Radical Scavenging Activity of Heartwood Extracts of $A$. confusa. The free radical scavenging activity of total crude extract and its derived fractions of $A$. confusa were assessed by DPPH assay. As shown in Figure 2, except for the $n$-hexane fraction, all the test samples showed a significant inhibitory activity against the DPPH radical. Among them, EtOAc and $\mathrm{BuOH}$ fractions were the best. The complete inhibition of DPPH radical by test samples was observed at a range of $5-10 \mu \mathrm{g} /$ $\mathrm{mL}$, and at the same dosage there was a similar free radical scavenging activity for (-)-ascorbic acid and (+)-catechin, both of which are well-known antioxidant compounds. Additionally, plant phenolics, in general, are highly effective free radical scavengers and antioxidants. The content of total phenolics in each fraction was determined spectrometrically according to the Folin-Ciocateu method and calculated as GAEs. Accordingly, the total phenolic content of the EtOAc fraction $(544.4 \mathrm{mg} / \mathrm{g})$ was significantly higher than that of the $\mathrm{BuOH}$ fraction $(358.3$ $\mathrm{mg} / \mathrm{g}$ ) and the water fractions $(235.1 \mathrm{mg} / \mathrm{g})$. These results indicate that the free radical scavenging activity of ethanolic extract of $A$. confusa heartwood can be effectively enriched in the EtOAc fraction. Moreover, the EtOAc fraction had 4.2-fold more mass than the $\mathrm{BuOH}$ fraction and was further investigated in this study for its phytochemical characteristics and in vitro antioxidant activity.

Inhibition of Hydroxyl Radical Induced DNA Strand Scission. To illustrate the protective effect of the EtOAc soluble fraction obtained from the heartwood of A. confusa on DNA strand scission, the $\Phi$ X174 RF1 DNA cleavage by hydroxyl radical generated by $\mathrm{UV}$ photolysis of $\mathrm{H}_{2} \mathrm{O}_{2}$ was measured. Figure 3 shows that neither $\mathrm{H}_{2} \mathrm{O}_{2}$ nor UV alone induced any DNA damage (lanes 2 and 3), but the combination of both resulted in almost complete conversion of supercoiled form DNA into its open circular form under our experimental conditions (lane 4). However, the EtOAc extract of the heartwood of $A$. confusa was able to greatly reduce the DNA strand scissions in a dose-dependent manner (lanes 5-9). When the

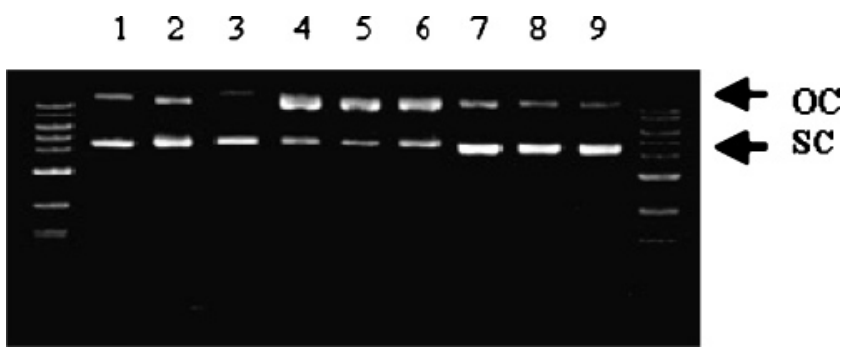

Figure 3. Protective effects of the EtOAc-soluble fraction from the heartwood extracts of $A$. confusa on DNA strand scission induced by $\mathrm{H}_{2} \mathrm{O}_{2}$ and UV. $\Phi X 174$ supercoiled DNA was exposed to UV alone (lane 2), $\mathrm{H}_{2} \mathrm{O}_{2}$ alone (lane 3), UV plus $\mathrm{H}_{2} \mathrm{O}_{2}$ (lane 4) or plus $\mathrm{H}_{2} \mathrm{O}_{2}$ in the presence of final concentrations of $1 \mu \mathrm{g} / \mathrm{mL}$ (lane 5), $10 \mu \mathrm{g} / \mathrm{mL}$ (lane 6), $100 \mu \mathrm{g} /$ $\mathrm{mL}$ (lane 7), $500 \mu \mathrm{g} / \mathrm{mL}$ (lane 8), and $1000 \mu \mathrm{g} / \mathrm{mL}$ (lane 9) of extract. Lane 1 represents native $\Phi \mathrm{X} 174$ supercoiled DNA without any treatment. Arrows indicate distinct forms of bacteriophage DNA, OC (open circular), SC (supercoiled).

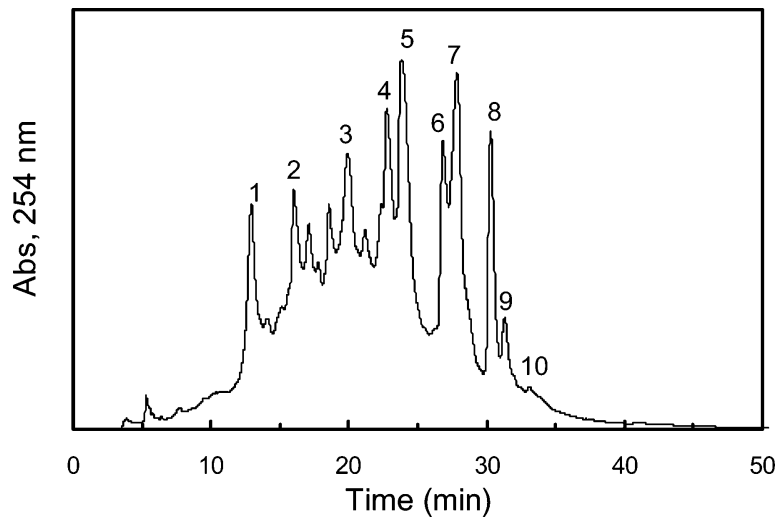

Figure 4. HPLC chromatogram of EA3 subfraction from the heartwood of $A$. confusa.

DNA was incubated with $100 \mu \mathrm{g} / \mathrm{mL}$ of EtOAc extract, the prevention of DNA strand scission was clearly observed (lane 7). Moreover, nearly complete protection by EtOAc extract was found at a dose of $500 \mu \mathrm{g} / \mathrm{mL}$ (lane 8).

TLC Analysis with DPPH Staining. For the rapid screening of free radical scavenging capacity, each subfraction from the EtOAc extract was detected in the TLC by the DPPH staining method. The appearance of yellow color in the spots has a potential value for the indirect evaluation of the free radical scavenging capacity of the test samples $(16,17)$. As expected, most EtOAc subfractions showed numerous migrated spots having strong intensities on the TLC plate that had been developed using $50 \% \mathrm{MeOH}$ solvent. Among them, however, the DPPH-stained TLC plate of EA3 subfraction exhibited stronger free radical scavenging capacity than the other subfractions. This result indicates that there are many antioxidants enriched in the EA3 subfraction.

Identification, Quantification, and DPPH Radical Scavenging Activity of Major Phenolic Antioxidants from the Heartwood of $\boldsymbol{A}$. confusa. The phenolic antioxidants of EA3 subfraction were purified and identified by using reverse-phase HPLC, MS, and 1D and 2D NMR spectrometry. Figure 4 shows the HPLC chromatogram of the EA3 subfraction, from which 10 phenolic compounds $(\mathbf{1}-\mathbf{1 0})$ were isolated and identified as 3,4-dihydroxybenzoic acid (1) (18), 2,3-trans-7,8,3',4'-tetrahydroxydihydroflavonol (2) (19), 3-hydroxy-4-methoxybenzoic acid (3) (20), 7,8,3',4'-tetrahydroxyflavanone (4) (19), 3,4dihydroxybenzoic acid methyl ester (5) (21), 3,7,8,3',4'-pentahydroxyflavone (6) (19), 7,8,3', $4^{\prime}$-tetrahydroxy-3-methoxy- 
Table 1. Content and $\mathrm{EC}_{50}$ of Major Flavonoids from the Heartwood of A. confusa in Scavenging DPPH Radicals

\begin{tabular}{|c|c|c|}
\hline flavonoids & $\begin{array}{l}\text { content }(\mu \mathrm{g} / \mathrm{mg} \text { of } \\
\text { EtOAc fraction) }\end{array}$ & $\begin{array}{l}\mathrm{EC}_{50} \\
(\mu \mathrm{M})\end{array}$ \\
\hline $\begin{array}{l}\text { 3,7,8,3', } 4^{\prime} \text {-pentahydroxyflavone (melanoxetin) } \\
7,8,3^{\prime}, 4^{\prime} \text {-tetrahydroxy-3-methoxyflavone (transilitin) } \\
3,4,2^{\prime}, 3^{\prime}, 4^{\prime} \text {-pentahydroxy-trans-chalcone (okanin) } \\
\text { 3,5,7,3, } 3^{\prime}, 4^{\prime} \text {-pentahydroxyflavone } \\
\quad \text { (quercetin, positive control) }\end{array}$ & $\begin{array}{r}33.4 \pm 1.1 \\
24.5 \pm 2.0 \\
5.8 \pm 0.3\end{array}$ & $\begin{array}{l}2.9 \\
3.2 \\
3.0 \\
3.6\end{array}$ \\
\hline
\end{tabular}

flavone (7) (22), 3,4-dihydroxybenzoic acid ethyl ester (8) (23), $3,4,2^{\prime}, 3^{\prime}, 4^{\prime}$ - pentahydroxy-trans-chalcone (9) (24), and 3,7,8, $3^{\prime}$ tetrahydroxy- $4^{\prime}$-methoxyflavone $(\mathbf{1 0})$, respectively. The ${ }^{1} \mathrm{H},{ }^{13} \mathrm{C}$ NMR, and MS spectral data of compounds 1-9 were in good agreement with the published values. All the phenolic compounds except compounds $\mathbf{2}$ and $\mathbf{6}$ were isolated from $A$. confusa for the first time. Compound $\mathbf{1 0}$ was obtained as a light-yellow amorphous solid material with a molecular formula of $\mathrm{C}_{16} \mathrm{H}_{12} \mathrm{O}_{7}$ based on HREIMS analysis. The ${ }^{1} \mathrm{H}$ NMR spectrum of $\mathbf{1 0}$ showed a typical ortho-coupled pattern for $\mathrm{H}-5(\delta 7.42,1 \mathrm{H}, \mathrm{d}$, $J=8.7 \mathrm{~Hz})$ and $\mathrm{H}-6(\delta 6.92,1 \mathrm{H}, \mathrm{d}, J=8.7 \mathrm{~Hz})$ of the A-ring and an ABX system for the $\mathrm{H}-2^{\prime}(\delta 7.76,1 \mathrm{H}, \mathrm{s}), \mathrm{H}-5^{\prime}(\delta 7.08$, $1 \mathrm{H}, \mathrm{d}, J=8.5 \mathrm{~Hz})$, and $\mathrm{H}-6^{\prime}(\delta 7.74,1 \mathrm{H}, \mathrm{d}, J=8.5 \mathrm{~Hz})$ protons of the B-ring. The position of the methoxy group was determined by the nuclear overhauser effect spectrometry experiment which confirmed an association of the $4^{\prime}$-methoxy group with $\mathrm{H}-5^{\prime}$. Additionally, a long-range correlation was observed in the heteronuclear multiple bond correlations (HMBC) spectrum from $4^{\prime}$-methoxy protons $(\delta 3.83,3 \mathrm{H}, \mathrm{s})$ to $\mathrm{C}-4^{\prime}(\delta 149.0)$. The ${ }^{13} \mathrm{C}$ NMR spectrum showed 16 carbon signals, which were assigned by heteronuclear single quantum coherence (HSQC) and HMBC as the following: $\delta 172.4$ (C-4), 149.7 (C-7), 149.0 (C-4'), 146.1 (C-3'), 145.9 (C-9), 144.5 (C-2), 137.2 (C-3), 132.7 (C-8), 124.3 (C-1'), 119.8 (C-6'), 115.1 (C-5, C-10), 114.7 (C$\left.2^{\prime}\right), 113.9(\mathrm{C}-6), 111.7\left(\mathrm{C}-5^{\prime}\right)$, and $55.6\left(4^{\prime}-\mathrm{OCH}_{3}\right)$. On the basis of these data, compound $\mathbf{1 0}$ is assigned the structure 3,7,8,3'tetrahydroxy-4'-methoxyflavone, and it is a new flavonoid and is reported here as a new natural product.

Furthermore, 6, 7, and 9 were the three major flavonoids in the EtOAc-soluble fraction, and their contents were 33.4, 24.5, and $5.8 \mu \mathrm{g}$ per mg of EtOAc extract, respectively (Table 1). In addition, as shown in Table 1, the $\mathrm{EC}_{50}$ values for DPPH radical scavenging activity of these three major flavonoids (compounds 6, 7, and 9) were $2.9,3.2$, and $3.0 \mu \mathrm{M}$, respectively. The free radical scavenging effect of these flavonoids was stronger than $3,5,7,3^{\prime}, 4^{\prime}$-pentahydroxyflavone (quercetin), a well-known antioxidant.

\section{DISCUSSION}

Reactive oxygen species (ROS) including the superoxide radical, hydroxyl radical, singlet oxygen, and hydrogen peroxide are often generated as byproducts of biological reactions or from exogenous factors (25). Some of these ROS play important roles in the pathogenesis of various serious diseases, such as neurodegenerative disorders, cancer, cardiovascular diseases, atherosclerosis, and inflammation (26). Thus, a potent scavenger of these species may serve as a possible preventive intervention for free-radical-mediated diseases (26). Recently, knowledge and application of potential antioxidant activities in reducing oxidative stresses in vivo have prompted many investigators to search for potent natural antioxidants from various plant sources (2831). This study shows that the heartwood extract of $A$. confusa exhibits excellent antioxidant activity. On the basis of the results of the free radical scavenging assay, as shown in Figure 2, the
EtOAc fraction from the heartwood of $A$. confusa exhibits a significant inhibitory activity against the DPPH radical.

In addition, hydroxyl radicals are considered to be the most active ROS, which can physically attack DNA to cause strand scission. Thus, incubation of $\Phi$ X174 supercoiled double-strand DNA with both $\mathrm{H}_{2} \mathrm{O}_{2}$ and UV resulted in complete conversion of supercoiled DNA to the open circular form. However, addition of the EtOAc extract from the heartwood of A. confusa to the reaction mixture substantially diminished the DNA strand scission induced by both $\mathrm{H}_{2} \mathrm{O}_{2}$ and UV. In particular, at a dose of $500 \mu \mathrm{g} / \mathrm{mL}$, the EtOAc extract almost completely protected supercoiled $\Phi \times 174$ DNA from hydroxyl-radical-induced strand scission (Figure 3). Keum et al. (14) demonstrated the antioxidant and anti-tumor-promoting activities of the methanolic extracts of heat-processed ginseng and also found that ginseng extracts could completely prevent DNA strand scission at a dose of $30 \mathrm{mg} / \mathrm{mL}$. However, in contrast with the heat-processed ginseng, a dosage of 60-fold less was required for the EtOAc extract to inhibit DNA damage. These results indicate that the EtOAc extract from the heartwood of A. confusa is an excellent antioxidant against hydroxyl radical damage.

Phenolic compounds are commonly found in plants, and they have been reported to have multiple biological effects, including antioxidant activity. Many studies have revealed that the phenolic content in plants can be correlated to their antioxidant activities $(15,32-34)$. In this study, the total phenolic content of the EtOAc fraction was higher than that of the $\mathrm{BuOH}$ fraction and the water fraction. These results reveal that the free radical scavenging effect of each soluble fraction from the ethanolic extracts of the heartwood of $A$. confusa also correlates closely with their phenolic contents. Furthermore, a rapid evaluation for antioxidants using TLC screening and DPPH-staining methods demonstrates that the EA3 subfraction exhibited the strongest free radical scavenging capacity among all subfractions of the EtOAc extract. And in the EA3 subfraction, 10 phenolic compounds (mainly flavonoids and phenolic acids) were isolated and identified by reverse-phase HPLC and NMR. Among these, compounds 6, 7, and 9 were the three major flavonoids, and their contents were 33.4, 24.5, and $5.8 \mu \mathrm{g}$ per $\mathrm{mg}$ of EtOAc extract, respectively. Additionally, these three flavonoids show a significant inhibitory activity against the DPPH radical, and the free radical scavenging effect of these flavonoids was stronger than that of quercetin $\left(3,5,7,3^{\prime}, 4^{\prime}\right.$-pentahydroxyflavone). It is known that the antioxidant activity of phenolic compounds is correlated to their chemical structure. In general, the free radical scavenging effect of phenolics (e.g., flavonoids and phenolic acids) depends mainly on the number and position of hydrogen-donating hydroxyl groups on the aromatic ring of the phenolic molecules (34-36). The aforementioned results demonstrate that the antioxidant activity of flavonoids increase with the 7,8-dihydroxy group (i.e., $o$-dihydroxy structure) in the A-ring.

In conclusion, $A$. confusa was used as a medicinal plant in Taiwan. However, in this study, we pointed out that this plant not only has those well-known bioactivities but also that the ethanolic extract from $A$. confusa heartwood exhibited an excellent antioxidant activity based on various in vitro assays. Furthermore, it is important to highlight that the specific phenolics contributed antioxidant activities in this target plant. Future studies should focus on the employment of modern medical chemical techniques to modify the structures of certain purified plant ingredients into better agents with high efficacy and activity. In addition, in vivo pharmacological researches also should be concerned. 


\section{ACKNOWLEDGMENT}

We thank the experimental forest of National Taiwan University for providing A. confusa materials as well as Shou-Ling Huang (Department of Chemistry, National Taiwan University) for NMR spectral analyses.

\section{LITERATURE CITED}

(1) Velioglu, Y. S.; Mazza, G.; Gao, L.; Oomah, B. D. Antioxidant activities and total phenolics in selected fruits, vegetables, and grain product. J. Agric. Food Chem. 1998, 46, 4113-4117.

(2) Exarchou, V.; Nenadis, N.; Tsimidou, M.; Gerothanassis, I. P.; Troganis, A.; Boskou, D. Antioxidant activities and phenolic composition of extracts from Greek oregano, Greek sage, and summer savory. J. Agric. Food Chem. 2002, 50, 5294-5299.

(3) Shahidi, F.; Janitha, P. K.; Wanasundara, P. D. Phenolic antioxidants. Crit. Rev. Food Sci. Nutr. 1992, 32, 67-103.

(4) Chung, K. T.; Wong, T. Y.; Huang, Y. W.; Lin, Y. Tannins and human health: A review. Crit. Rev. Food Sci. Nutr. 1998, 38, 421-464.

(5) Pietta, P. G. Flavonoids as antioxidants. J. Nat. Prod. 2000, 63, $1035-1042$

(6) Owen, R. W.; Giacosa, A.; Hull, W. E.; Haubner, R.; Spiegelhalder, B.; Bartsch, H. The antioxidant/anticancer potential of phenolic compounds isolated from olive oil. Eur. J. Cancer $\mathbf{2 0 0 0}$, $36,1235-1247$

(7) Yang, C. S.; Landau, J. M.; Huang, M. T.; Newmark, H. L. Inhibition of carcinogenesis by dietary polyphenolic compounds. Annu. Rev. Nutr. 2001, 21, 381-406.

(8) Sakakibara, H.; Honda, Y.; Nakagawa, S.; Ashida, H.; Kanazawa, K. Simultaneous determination of all polyphenols in vegetables, fruit, and teas. J. Agric. Food Chem. 2003, 51, 571-581.

(9) Clark-Lewis, J. W.; Porter, L. J. Phytochemical survey of the heartwood flavonoids of Acacia species from arid zones of Australia. Aust. J. Chem. 1972, 25, 1943-1955.

(10) Pietarinen, S. P.; Willför, S. M.; Sjöholm, R. E.; Holmbom, B. R. Bioactive phenolic substances in important tree species. Part 3: Knots and stemwood of Acacia crassicarpa and A. mangium. Holzfoschung 2005, 59, 94-101.

(11) Kan, W.-S. Leguminosae. In Manual of Medicinal Plants in Taiwan; Kan, W.-S., Ed.; National Research Institute of Chinese Medicine: Taipei, Taiwan, 1978; Vol. 2, pp 239-240.

(12) Chang, S.-T.; Wu, J.-H.; Wang, S.-Y.; Kang, P.-L.; Yang, N.S.; Shyur, L.-F. Antioxidant activity of extracts from Acacia confusa bark and heartwood. J. Agric. Food Chem. 2001, 49, $3420-3424$

(13) Gyamfi, M. A.; Yonamine, M.; Aniya, Y. Free-radical scavenging action of medicinal herbs from Ghana: Thonningia sanguinea on experimentally induced liver injuries. Gen. Pharmacol. 1999, $32,661-667$

(14) Keum, Y. S.; Park, K. K.; Lee, J. M.; Chun, K. S.; Park, J. H.; Lee, S. K.; Kwon, H.; Surh, Y. J. Antioxidant and antitumor promoting activities of the methanol extract of heat-processed ginseng. Cancer Lett. 2000, 150, 41-48.

(15) Kujala, T. S.; Loponen, J. M.; Klika, K. D.; Pihlaja, K. Phenolics and betacyanins in red beetroot (Beta vulgaris) root: Distribution and effect of cold storage on the content of total phenolics and three individual compounds. J. Agric. Food Chem. 2000, 48, $5338-5342$

(16) Soler-Rivas, C.; Carlos Espín, J.; Wichers, H. J. An easy and fast to compare total free radical scavenging capacity of foodstuffs. Phytochem. Anal. 2000, 11, 330-338.

(17) Choi, C. W.; Kim, S. C.; Hwang, S. S.; Choi, B. K.; Ahn, H. J.; Lee, M. Y.; Park, S. H.; Kim, S. K. Antioxidant activity and free radical scavenging capacity between Korea medicinal plants and flavonoids by assay-guided comparison. Plant Sci. 2002, $163,1161-1168$
(18) Flamini, G.; Antognoli, E.; Morelli, I. Two flavonoids and other compounds from the aerial parts of Centaurea bracteata from Italy. Phytochemistry 2001, 57, 559-564.

(19) Foo, L. Y. Configuration and conformation of dihydroflavonols from Acacia melanoxylon. Phytochemistry 1987, 26, 813-817.

(20) Ding, H.-Y.; Lin, H.-C.; Teng, C.-M.; Wu, Y.-C. Phytochemical and pharmacological studies on chinese Paeonia species. J. Chin. Chem. Soc. 2000, 47, 381-388.

(21) Miyazawa, M.; Oshima, T.; Koshio, K.; Itsuzaki, Y.; Anzai, J. Tyrosinase inhibitor from black rice bran. J. Agric. Food Chem. 2003, 51, 6953-6956.

(22) Malan, E. 7, 8, 4'-Trihydroxy-3, 3'-dimethoxyflavone from the heartwood of Acacia nigrescens. Phytochemistry 1993, 33, 733734.

(23) Baderschneider, B.; Winterhalter, P. Isolation and characterization of novel benzoates, cinnamates, flavonoids, and lignans from riesling wine and screening for antioxidant activity. J. Agric. Food Chem. 2001, 49, 2788-2798.

(24) Hoffmann, B.; Hölzl, J. Chalcone glucosides from Bidens pilosa. Phytochemistry 1989, 28, 247-249.

(25) Cerutti, P. A. Oxidant stress and carcinogenesis. Eur. J. Clin. Invest. 1991, 21, 1-11.

(26) Aruoma, O. I. Free radicals, oxidative stress, and antioxidants in human health and disease. J. Am. Oil Chem. Soc. 1998, 75, 199-212.

(27) Ames, B. N.; Gold, L. S.; Willet, W. C. The causes and prevention of cancer. Proc. Natl. Acad. Sci., U.S.A. 1995, 92, 5258-5265.

(28) Zi, X.; Mukhtar, H.; Agarwal, R. Novel cancer chemopreventive effects of a flavonoid antioxidant silymarin: inhibition of mRNA expression of an endogenous tumor promorter TNF $\alpha$. Biochem. Biophys. Res. Commun. 1997, 239, 334-339.

(29) Ohsugi, M.; Fan, W.; Hase, K.; Xiong, Q.; Tezuka, Y.; Komatsu, K.; Namba, T.; Saitoh, T.; Tazawa, K.; Kadota, S. Active-oxygen scavenging activity of traditional nourishing-tonic herbal medicines and active constituents of Rhodiola sacra. J. Ethnopharmacol. 1999, 67, 111-119.

(30) Liu, F.; Ng, T. B. Antioxidative and free radical scavenging activities of selected medicinal herbs. Life Sci. 2000, 66, 725735.

(31) $\mathrm{Hu}, \mathrm{C}$; ; Kitts, D. D. Studies on the antioxidant activity of Echinacea root extract. J. Agric. Food Chem. 2000, 48, 14661472.

(32) Sato, M.; Ramarathnam, N.; Suzuki, Y.; Ohkubo, T.; Takeuchi, M.; Ochi, H. Varietal differences in the phenolic content and superoxide radical scavenging potential of wines from different sources. J. Agric. Food Chem. 1996, 44, 37-41.

(33) Lavelli, V.; Peri, C.; Rizzolo, A. Antioxidant activity of tomato products as studied by model reactions using xanthine oxidase, myeloperoxidase, and copper-induced lipid peroxidation. $J$. Agric. Food Chem. 2000, 48, 1442-1448.

(34) Cai, Y.; Luo, Q.; Sun, M.; Corke, H. Antioxidant activity and phenolic compounds of 112 traditional Chinese medicinal plants associated with anticancer. Life Sci. 2004, 74, 2157-2184.

(35) Das, N. P.; Pereira, T. A. Effects of flavonoids on thermal autoxidation of palm oil: structure-activity relationships. J. Am. Oil. Chem. Soc. 1990, 67, 255-259.

(36) Rice-Evans, C. A.; Miller, N. J.; Paganga, G. Antioxidant properties of phenolic compounds. Trends Plant Sci. 1997, 2, $152-159$.

Received for review March 10, 2005. Revised manuscript received May 30, 2005. Accepted June 1, 2005. Thanks to the National Science Council for financial support.

JF050550M 